\title{
A Study on the Construction of International Business Law of Bilingual Teaching from the Perspective of $\mathrm{CBI}$
}

\author{
Qi Li \\ School of Economic and Management, NINGBO University of Technology, NINGBO, P. R. China, \\ 315211 \\ liqi2001@sohu.com
}

Keywords: CBI; International business law; Bilingual teaching

\begin{abstract}
Cultivating the compound talents, actively implementing teaching reform in colleges and universities in China, CBI is to combine language skills based on the content of learning a new teaching idea, an internal agreement between its characteristics and talents cultivation objective in international business law. In order to obtain better teaching effect, the bilingual teaching of international business law in the international economic and trade professionals introduces CBI ideas to optimize the traditional bilingual teaching mode.
\end{abstract}

\section{Introduction}

On the policy of strengthening the undergraduate teaching to improve teaching quality in colleges and universities, the Ministry of education encourages to carry out bilingual teaching in colleges and universities. Bilingual teaching is the essential means of training innovative talents which all universities have introduced policies involved. On bilingual teaching and balance the relationship between foreign language and professional knowledge by lots of research at home and abroad, there has been a lot of new teaching methods, which rely on the contents of teaching

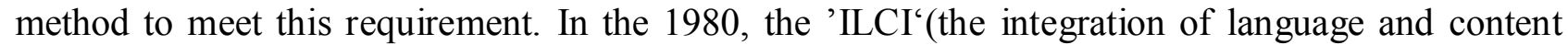
instruction) attracted great attentions[1,2], a teaching method known as contend based instruction,( referred to as CBI). CBI method is foreign language teaching based on the subject content, also called "content-based language teaching", "integration of language teaching". It is based on the communicative approach to language teaching and development of a communicative teaching method. CBI is language teaching reform and innovation in education movement.

Briton believed that CBI was an established combination of subject and language teaching objectives, current areas of academic instruction and second language skills combining teaching.[1]. Crandall. Tucker said: "CBI is a method of language teaching, combined with the Select topic from the content sand tasks." [2]. CBI changed the traditional teaching that was separated in the process of language learning and knowledge learning. On CBI, content dominated the teaching and received full attention in class. CBI is the idea of language as a medium of learning various subjects that it becomes the source of language learning [3]. Stryker and Beaver believe that when the language as a medium of learning knowledge, when the combination of language learning and teaching, and CBI creates the most ideal conditions of foreign language and second language learning[4]. CBI benefits of the teaching language of form, function, and significance not been split which ensure that the class have higher requirements for cognitive activities by motivation enhancement, increased interest, thus enriching the students' cognitive development[5]. CBI is a teaching method of no machinery, rigidly requiring the use of teaching techniques, teaching activities can be suitable for any teaching activities[6].

\section{The Problems in Bilingual Teaching of International Business Law}

The necessity of bilingual teaching of international business law. International business law enables students to grasp the basic knowledge of international business law, including not only a large number of international treaties and laws of the international trade practice but also the national foreign-related commercial laws and regulations as well as relevant judicial interpretations. 
Its area covers civil law and common law system that most of these legal texts are the original, English translation text not be very accurate.

Bilingual teaching of international business law improves students' ability to use the foreign language reading and exercises students' cognitive capacity and oral expression skills to develop an international perspective international talents. It is necessary to determines the course of bilingual teaching by its international teaching contents and teaching target.

The present bilingual teaching mode of international business law. Translation. The contents of teaching materials are explained in Chinese-English translation. This is a primary mode of bilingual teaching between teachers and students of low English level and some scattered specialized vocabulary. The mode cannot meet the requirements of international law expertise and language teaching.

Cross. It needs to transform the language in teaching process in Chinese and English, the proportion of teaching in two languages is difficult to control that does not balance language learning of knowledge and expertise.

Full English. This mode requires students and teachers in pure English teaching environment, strictly demands on English communication environment that students even have a fear of it.

The three model was unable to fulfill the bilingual teaching of international law because of their advantages and disadvantages[7].

Choice of international business law textbooks. International business law book is complex and abstract. The course has 32 classroom hours in a semester, the teacher should choose the most representative, practical sections from ten chapters to students. In general, domestic and international business law textbooks can be divided into two types in English and Chinese. It's hard to Choose suitable original introduction of English teaching materials of international business law, because the biggest problem exits that the original textbook's system and content are not in accordance with national conditions, even lack of the introduction of Chinese law. Our Chinese law is civil law, but British and American law textbooks compiled is a style of case law, so students are difficult to understand the content conflict. The traditional case method only requires students to remember a case, not truly mastering basic theories through cases and rules of international business law.

\section{Constructing New Mode of Bilingual Teaching of International Business Law Based on CBI}

Introduction with self-made textbooks. Generally speaking, bilingual teaching is the best use of original foreign textbooks, teachers introduce reasonable English textbooks should be based on a different course, treated differently and adjusting the content. For the international business law textbooks to foreign scholars base on foreign law and its' basic conditions for its own economic development and legal system construction services. As to Chinese national conditions and the legislation, there is a big difference with other countries, if the teachers blindly copy foreign original edition textbooks, students received a foreign legal education and could not be applied in the reality of our country, so teachers may add or subtract the contents of teaching materials. Teaching content focuses on international economic and trade specific in international economic and trade professional, teachers can make teaching handout according to the professional courses. Thus, Students are not completely strange to the teaching content, while teachers teach better combination of expertise and language.

Diversification of Teaching. CBI has three models: Immersion Model, Sheltered Subject Instruction; Adjunct Language Instruction; The Theme-based Instruction, content for Practice [8]. According to the specific circumstances, CBI was designed into Adjunct Language Instruction, then Sheltered Subject Instruction as a transition and finally the Immersion Model $[9,10]$.

Using Progressive Teaching Methods. The semester can be divided into three stages. At first stage, teachers taking Adjunct Language Instruction will told focus and difficulties in English and explain content in Chinese while students feel some difficulty in bilingual study. Then Sheltered Subject Instruction, teachers introduce more contents in English with students gradually improved English level. At last Immersion Model, then teachers can immerse totally students into English 
language contexts to further develop their science thinking. Teachers can enlighten the students active thinking in various ways by using case studies, role plays, comparative law, group discussions and enhance students ' participation in the sense of reality by animation, pictures, original English display content. (Y. H. Xu 2014)

Improving the Appraisal System. The best way to test students' integrated capacity should combine written and interview, especially increase usual results to measure and encourage students' class statement actively. According to class statement' times and quality, It strengthens students of process management and quality training. Teachers assess to students divided into four aspects: firstly, self-test problem; teachers in teaching website announced self-test problem in each chapter, students need complete network self-test problem in provides time; secondly, final exam; thirdly, for semester small papers; fourthly, students' involvement and the usual case completion. Teachers detailed record the students participating in the network group and class discussions to better training students' professional knowledge and language abilities.

The Organization of Bilingual Case Teaching. Teachers prepare international business law case set to reduce students reading difficulties that develop their independent reading and thinking skills and guide students to use network resources, such as the timely collection of original foreign English cases as extracurricular reading material by providing Chinese language profile, the dispute, and so on. 40 students divide into 6groups in a case study, so every group needs complete two case studies in the semester.

Compared with the traditional method, CBI teaches students to be active and positive while the teacher is passive. Teachers recommend case legal video for students to perfect legal and literacy in fun, "small class teaching" helps teachers observing students in a timely manner, and optimizes the progress of bilingual teaching.

Strengthening the Training of Bilingual Teachers. Bilingual teachers training can start from several aspects: firstly, selecting professional teachers to abroad study; secondly, hiring foreign experts rich in teaching experience for teachers' oral training to improve their English level; fourthly, inviting foreign experts to take part in bilingual teaching curriculum through two-way communication.

\section{Conclusions}

CBI ideas update the traditional language teaching mode and construct the teaching mode of integration of content and language. CBI cultivate students by Student-centered, student-led in the classroom, after-school teacher-student communication and feedback. However, the implementation of international law bilingual teaching for professional teachers presents new challenges based on the CBI. Collage should strengthen incentives to ensure the stability of existing bilingual teachers of workload and great pressure.

\section{Acknowledgments}

Ningbo University of Technology higher education project of 2015

\section{References}

[1] Briton.D. Snow. M. A. and Weche, M. B: Content-based Second Language Instruction. (Boston Publishers, U.S.A.1989:2)

[2] Crandal, J and Tucker, G.R: Content-based Instruction in Second and Foreign Languages Sage. Foreign Language Education: Issues and Strategies . (Newbury Park, CA ,1990)187

[3] P.H.Yuan and M.Yu: foreign language teaching and research, 2008 (1): 59-64

[4] Stryker S. B, and B. L. Leaver: Content based Instruction in Foreign Language Educatio 
(Georgetown University Press, 1997:3)

[5] Grabe. W. and F. L Stoller: The Content based Classroom: Perspectives on Integrating Language and Content. (New York: Longman. 1997) 5-21

[6] Richards, J. C and Roger T. S. Approaches and Methods in Language Teaching [M]. (Cambridge University Press, Cambridge: 2001 )20

[7] Leaver, B. L, and S. B. Stryker: Foreign Language Annual, 1989, No.22, 269

[8] W. Zhang: Age of finance. 2016. 2:1No.95. 203 (In Chinese).

[9] Y. Z. He: Science and education, 2015.No. 251. (In Chinese).

[10] Y.H. Xu: Journal of Hunan University of Commerce (Bimonthly), 2014.No.4, 122-124. (In Chinese). 